\title{
FIDELITY TO WESTERN METAPHYSICS: A CHALLENGE TO AUTHENTIC AFRICAN EXISTENCE ${ }^{1}$ \\ DOI: http://dx.doi.org/10.4314/ft.v5i1.1
}

\section{Innocent I. ASOUZU, Ph.D \\ Professor of Philosophy, Department of Philosophy, University of Calabar}

\begin{abstract}
In this paper, I tried to show how Western attitude to reality can be traced to the divisive exclusivist type of mind-set behind Aristotle's conception of the world. I gesture toward some of the severest consequences of approaching the world with such a mind-set, and how such has complicated matters in some of the major debates in African philosophy. By recourse to ibuanyidanda or complementary philosophy, the author explores ways of addressing some of the challenges approaches of this kind present in view of resolving issues that have relevance for authentic existence. Keywords: Aristotle, ibuanyidanda, complementary ontology, Tempelsian Damage, ihe mkpuchi anya, missing link of reality.

\section{Introduction: Aristotle's Legacies and Western Metaphysics}

History is replete with accounts of great people who influenced and determined the ideas of whole generations of thinkers. In the case of Western Philosophy, it is common knowledge that Aristotle played this all important role (CORETH 1963, 18; COPLESTON 1960, 30; HIRSCHBERGER 1976, 163, 183, 163-208). His influence was even such that his ideas, at a certain point in history, "were acclaimed by the Church as criteria of truth which were to be accepted by all Christians just as they accepted the traditional dogma of the Church. Anyone who contradicted Aristotle was to be adjudged guilty of heresy" (SAHAKIAN 1969, 103). Aristotle's vision of the world goes back to Plato who "demanded that the wise, the professional philosopher should be the statesman, the absolute ruler" (POPPER 1977, 12). ${ }^{2}$ For Karl Popper, it was an elitist, exclusivist and intolerant type of attitude that even envisioned an institutionalised type of correction for dissenters in the manner of the inquisition. Commenting further on this attitude, Karl Popper adds: "Since the time of Plato megalomania has been the commonest professional sickness of philosophers" (POPPER 1977, 12). Even if Plato targets philosophers, as Karl Popper suggests he does, it was Aristotle who, in his doctrine of being, sought to systematise such extremist, elitist, exclusivist views to a folk's ideology. This is most evident in his first philosophy where for him substance is being in its fullest as opposed to accidents which inhere in substances and depend on them for their existence. Thus he expounds: "if these are not substance, there is no substance and

Presented at the Philosophy Week of National Association of Philosophy Students Seat of Wisdom Seminary Branch, Umuahia, Abia State. 12 March 2016 at 9.00 am

${ }^{2}$ Translated to English from the German original by me
\end{abstract}


no being at all; for the accidents of these it cannot be right to call beings" (Book B, 5). Just as substance is infinitely more superior than accidents, the first philosophy takes precedence over the other sciences, he calls "ancillary sciences", because the first philosophy probes into the causes of things; and into the structure of being in its fullest.

All things and persons dealing with the ultimate cause of all things, with being in its fullest, have for him the character of wisdom. This is the case with the master worker who as the man of wisdom is duty bound to direct and lead the manual workers. He thus expounds:

Hence we think also that the masterworkers in each craft are more honourable and know in a truer sense and are wiser than the manual workers, because they know the causes of the things that are done ...but the point of our present discussion is this, that all men suppose what is called Wisdom to deal with the first causes and the principles of things; so that, as has been said before, the man of experience is thought to be wiser than the possessors of any sense-perception whatever, the artist wiser than the men of experience, the masterworker than the mechanic, and the theoretical kinds of knowledge to be more of the nature of Wisdom than the productive. (Book A, 1)

\section{Continuing Aristotle concludes:}

the wise man knows all things, as far as possible, ... secondly, that he who can learn things that are difficult, and not easy for man to know, is wise (senseperception is common to all, and therefore easy and no mark of Wisdom); again, that he who is more exact and more capable of teaching the causes is wiser, in every branch of knowledge; and that of the sciences, also, that which is desirable on its own account and for the sake of knowing it is more of the nature of Wisdom than that which is desirable on account of its results, and the superior science is more of the nature of Wisdom than the ancillary; for the wise man must not be ordered but must order, and he must not obey another, but the less wise must obey him. (ARISTOTLE Book A, 2)

One thing is evident, Aristotle attends to his ontological themes with a bifurcated, exclusivist and elitist type of mind-set that extolls reason; and the man of wisdom, who has the prerogative to lead and direct the unwise. It is this ontology that found far reaching acceptance in Western scheme of things - one that extolls reason-, and which sees its destiny given in the man of reason that leads the unwise. This is what has come to be regarded in many quarters as the triumph of "Western rationality"; a credible platform for Western expansionist attitude of domination, subjugation and conquest against the others it perceives as alien, less wise, accidental and dispensable. Dallmayr sees deep-rooted connection in this regard to the militarism of ¿OAlexander the Great, Aristotle's pupil. As if heeding to the injunction "that barbarians should be governed by the Greeks" as recorded in Aristotle's Politics, Alexander the Great "embarked on his far-flung military conquest and imperial 
ventures" (DALLMAYR 2005, 53). For Dallmayr "the main justification for this claim was the Greeks' (supposed) greater rationality and self-control as compared with the barbarians" $(2005,53)$. This is why even in contemporary geopolitics Dallmayr sees the same Aristotelian mentality being fostered by most Western powers as they seek to be in control of most things strategic, and most especially nuclear weapons, under the supposition that they alone have the higher rationality and needed self-control to use them properly (DALLMAYR 2005, 53). Here, Aristotle is sometimes described by Westerners as "the master of all who know" (ASANTE 1987, 8).

\section{Aristotelianism, the First Philosophy (Wisdom) - Ancillary Science Dichotomy}

The mind-set underlying Aristotle's doctrine of being has tremendous impact on the unmediated way scientific debates are conducted in the West. Apart from very few exceptions, most contentions in Western philosophy, in diverse guises, are conducted in the mode of Aristotle's substance (essence) - accidents dichotomy and canter unevenly around this distinction. We see this quite given in the scholastic tradition. Their diverse modes of understanding the term "substance" notwithstanding most 17th century Western philosophers used the term in a bifurcated exclusivist mode, to refer to the ultimate constituents of reality on which everything else depends after the mind set of Aristotle. We see this trend given in the philosophies of Descartes, Spinoza, and Leibniz. This trend continued with subsequent philosophers: with Christian Wolf, Immanuel Kant, and Friedrich Hegel, etc., and even into $20^{\text {th }}$ century as exemplified in Martin Heidegger's fundamental ontology.

The same thing is applicable where Aristotle's first philosophy (wisdom) ancillary science dichotomy contributed immensely in the unhealthy rivalry that has ever characterised scientific debates in the West as is epitomised in the irreconcilable rationalist - empiricist positions. One is then not surprised, when in a state of changed fortune, the very disciplines Aristotle designates as ancillary sciences, turn around to lord it over metaphysics. This is the case with the hostile positivist critique of metaphysics which its proponents reject as meaningless (AYER 1968). Foregoing is a scientific attitude that smack on arrogance; and one that negates the possibility of the subject matters of all the sciences being harmonised; and brought under a roof. We see the same trend given in the existentialist-phenomenological dichotomies and in all those instances where stakeholders relate to reality in exclusivist absolute mode devoid mediation. It is this tendency to focus only on that aspect of reality one considers essential that I characterise as 'the philosophy of essence'. What is most remarkable is that approaches of this kind almost always lead to deadlocks and contradictions since they make no provision for mutual harmony between the fundamental ontological categories of which reality is constituted. This is why, for $\checkmark$ example, those brands of existentialism that focus solely on existence as constitutive .oof their subject matter, end up negating their position when suddenly the existential $\approx$ dimension of reality reverts to the very essence of what they intend. 


\section{Tempelsian Damage and the Static - Dynamic Dichotomy}

We cannot talk of Western philosophy and metaphysics without taking a look at African philosophy which shares much in common with this tradition. Philosophy as an academic discipline in Africa in the last decades has much to do with Placide Tempels' Bantu philosophy (CHIMAKONAM web). Placide Tempels' "Bantu Philosophy" shows clear evidence of his Aristotelian heritage. This is why, approaching his task with a bifurcated elitist type of mind-set, and his sympathy for the Bantu notwithstanding Tempels came to the derogatory conclusion that "We [the West] can conceive the transcendental notion of 'being' by separating it from its attribute, 'Force', but the Bantu cannot" (TEMPELS 1959, 50). This observation will have tremendous consequences for the way philosophy is done in Africa. Thus for Tempels the ability to grasp the "transcendental notion of being", Aristotle's being qua being or being in its fullest is a prerogative of the West: an arrogant claim that lays claims to a superior notion of being while denigrating that of the Bantu. Thus "force", the Bantu notion of being, as Tempels sees it, is world-immanent, nontranscendent, magical and superstitious.

Ironically and quite surprisingly, subsequent African scholars sought to appropriate "force" as the authentic dynamic notion of being for which Africa should be known. This for them is against a static notion of being which they regard as something uniquely Western. This is what I call the 'Tempelsian Damage' where African scholars appropriate and universalise a derogatory notion of being in their inordinate zeal to carve out a unique conception of reality they call their own. Such derailments and contradictions are possible only when we approach reality with a bifurcated and exclusivist type of mind-set. Approaching reality in this mode has never boded well for African philosophy since it has greatly contributed to stifling its growth where some of its practitioners operate with the romantic idea of focusing only on those things they deem unique to African experience of reality. We see this given mostly where many hermeneutical approaches in African philosophy have degenerated to spirited attempts at describing, reclaiming or even proclaiming what they consider unique to African culture devoid of analytic philosophical content. The same applies in those instances where some African scholars assume that individualism is the hallmark of Western attitude to life as against a communalistic African lifestyle. Here individualism and communalism are handled as if they are diametrically opposed categories that cannot coexist. We arrive at the same odd conclusions by assuming that Africans are uniquely religious, compassionate, and humane. Reasoning in this exclusivist dichotomising mode merely succeeds in deepening the divide in human consciousness in a world it shares with others.

African notion of being is supposed to be dynamic, but not in Placide Tempels' derogatory sense. Rather, it is dynamic in a complementary mutually $\mathbf{C}$ related mode in keeping with the ideas of traditional African philosophers of the ¿ocomplementary system of thought. Contrary to Tempels' views, and of many who

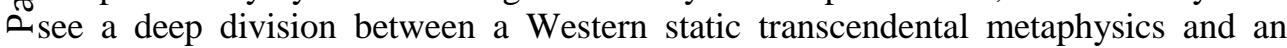
African dynamic world immanent pre-deterministic metaphysics, the terms dynamic 
and static are not exclusivist categories as to suggest that they cannot coexist within any given framework. There is a moment of the static that bestows some permanence in the dynamic, just as the dynamic is the condition of possibility for conceptualisation of the static. In other words both concepts are better handled within a mutual complementary framework to uphold their authenticity.

\section{Western Metaphysics and some Philosophical Challenges in African Philosophy: Placide Tempels Redivivus}

Severe criticisms on Tempels' [Bantu Philosophy] notwithstanding, many Western practitioners of African philosophy have surprisingly persisted in some of his mistakes to the extent that one easily sees Placide Tempels' spirit reincarnating in their works. This shows how difficult it is to abdicate an exclusivist, elitist type of mind-set that has been internalised in long years of education, socialisation and indoctrination. Typical examples abound: Thus in seeking what he calls "creative encounter" between world cultures, Heinrich Beck in the $21^{\text {st }}$ century attends to his task with the same excessive urge that seeks monopoly of reason. For him the precondition for such encounter subsists in recognising the fact that Europe has the tendency "to differentiate and to structure reality rationally" while Afro-Asiatic area "developed an accordingly sensitive, intuitive ability and basic habit" (BECK 2002, 64). Beck is not alone in excesses of this kind. It never ceases to confound considering the mind-set with which many Western scholars still seek dialogue with their African counterparts in the name of doing African philosophy. Many prominent members of intercultural philosophy, for example, who seek dialogue with African philosophy do so often with incorrigible obstinate and arrogant spirit; and so much so that they make the same pronouncements today about Africans just as Hegel and Tempels did many centuries and decades ago. Kimmerle in seeking dialogue at the University of Nairobi, equally doubted, indirectly, the capacity of his host to handle abstract epistemological and ontological philosophical puzzles without watering these down to simple practical ethical questions. Referring to the way his host interlocutors conducted philosophical investigations during one of his numerous encounters at this university, he sarcastically observed "Man wird zuerst geneigt sein, in dieser Art der Fragestellung oder Aufgabenstellung eine grobe Vereinfachung $\mathrm{zu}$ sehen. Differenzierte und komplizierte Thesen werden zurückgebracht auf einfache Formulierungen. Das scheint eher passend für einen Besinnungsaufsatz in der Oberstufe des Gymnasiums als für eine PhilosophieVeranstaltung an der Universität. Bei etwas genauerem Hinhören bemerkt man, dass vielen philosophischen Fragen, die erkenntnistheoretisch oder ontologisch gemeint sind, eine ethische Wendung gegeben wud." (One is inclined to see blundering oversimplification in this form of interrogation or investigative standard. Differentiated and complicated Theses are reduced to simplistic formulations. This onseems to be more appropriate for intellectual work of a [German] senior secondary

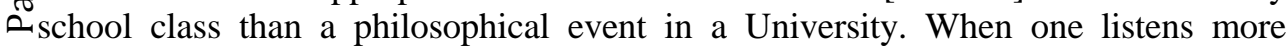
carefully one notices that many philosophical questions of epistemological or 
ontological relevance take an ethical turn" (KIMMERLE 2008). ${ }^{3}$ It is welcome and positive development when Kimmerle, in his reply to my criticisms acknowledges the inappropriateness of scientific encounters conducted in this fashion (KIMMERLE 2008, 102). ${ }^{4}$ I ascribe contradictory behaviours of this kind to the impact of our tension-laden ambivalent existential situations and ihe mkpuchi anya (phenomenon of concealment): These are those mechanisms and phenomena that compel actors to always do the opposite of what they intend and desire in the face of their most cherished interests (ASOUZU 2013). In this case, contrary to upholding healthy intercultural dialogue the primary purpose of his visit, Kimmerle turns around subverting the same with an attitude that is repugnant and contradictory to his major theory of intercultural dialogue.

The same mindset underlies their expectations that contemporary African philosophers should evolve their own special brands of philosophy instead of copying the works of European philosophers (ASOUZU 2007a, 30). This is what I designate as "Copycat Philosophy" - their own version of "Philosophy of Stolen Legacy". This is why, approaching African philosophy with near mixture of sympathy and contempt, many of them hardly believe that contemporary philosophers of African descent can articulate philosophy beyond the collective worldview of their people. One is then not surprised at the spirited effort some Western practitioners of African Philosophy are making to fill in a systematic gap they think is lacking in African philosophy. Interestingly, they think that they alone have the capacity to fill in this rigorous intellectual gap: Something quite reminiscent of Aristotle's observation that "the wise man knows all things, as far as possible ... secondly, that he who can learn things that are difficult, and not easy for man to know, is wise" (ARISTOTLE Book A, 2). Thus in the name of doing African philosophy they, like in Tempels' "Bantu Philosophy", make spirited efforts to propose their own theories which they tag "African Democracy", "African Ethics", "African Politics" etc. Ignoring systematic works of African scholars in the same subject matter; and in the mood of people in a rescue mission, they aspire most ambitiously to be the first in the area just as Tempels before them. This time, they prefer to use the works of renowned contemporary African scholars as mere ethnographic raw materials to construct and validate preferred theories. By so doing, they deepen the belief that works of contemporary African philosophers are best handled as collective African worldviews. Worst still is when they discredit systematisation, but seek to reintroduce same under more liberal guises in view of seeking dominance (ASOUZU 2013, 36). This is what I designate as their "systemless systems". It would hardly suffice today, in African philosophy, to operate under such anonymous and unsolicited tags as "African Politics", "African Aesthetics", "African Epistemology", etc., since philosophical statements need valid Naddresses and profiles beyond such collective characterisations. If one does not wish $\sqrt{80}$

${ }^{3}$ Translation from the original by me

${ }^{4}$ Translation from the original by me 
to take responsibility for ones ideas, but would rather prefer to speak anonymously, one should let it be.

Considering the good intentions underlying some approaches of this kind, one can say that more often than not, and quite unconsciously, researchers generally are victims of what I call 'the phenomenon of unintended ethnocentric commitment' deriving from attaching excessive importance to the worth of their cultural heritages. In this way, they approach others with an elitist bifurcated and exclusivist type of mind-set, to see differences in a way that favours their own conceptual schemes, but quite unintentionally. The phenomenon of unintended ethnocentric commitment is an affliction of the mind that can complicate good relationship between researchers of diverse ethnic backgrounds, just as it can infringe on scientific integrity. This is why I am of the opinion that it deserves more attention than the issue relating to value oriented bias in inquiry. Hence, all forms of ethnocentric induced methods of theorising that inordinately extoll differences, present grave challenges to philosophy. For this reason, currents like Philosophy of Stolen Legacy, Copy-Cat Philosophy, and the Black Athena Debate are nothing other than variants of extremist forms of ideology masquerading under the name of scientific philosophy (ASOUZU 2007B, 110-114). These approaches overlook the fact that all human achievements and failures can be grasped only within a complementary framework to remain credible. Hence, an in-depth understanding and explanation of the mechanisms and phenomena that compel actors to act contrary to their will and desires constitutes one of the greatest tasks of philosophy in heterogeneous multicultural context as we have it in the world today.

\section{The Human Person in Tension-Laden Ambivalent Existential Situations}

Even if fidelity to the metaphysics of Aristotle contributed greatly in enhancing the tendency to embrace reality with a dichotomising and exclusivist type of mind-set in the West, it may be wrong to assume that this phenomenon is something peculiar to the West. This tendency is a universal human problem deriving from the structure and internal workings of human consciousness itself; and holds sway whenever the conditions are favourable. Generally, human consciousness tends to act in discriminative, bifurcated exclusivist mode because of the ambivalent tension laden character of all existential situations. In addition to this, all human existential situations are beclouded by what I call ihe mkpuchi anya (phenomenon of concealment), and are subject to the challenges arising from our primitive instinct of self-preservation. These existential challenges compel us to act often against our will in the most baffling paradoxical modes in the face of our most cherished interests. Exposed to these existential challenges, we tend to do almost always the opposite of what we intend and wish; and so much so that precisely those things we condemn Oand abhor are the very things we insist on doing, just as we refrain from doing those odhings we praise to high heavens. This is why stressed by these existential challenges, こlawgivers easily turn to lawbreakers; all in a bid to satisfy their most cherished interests. It is an existential condition that blindfolds; and which easily makes us 
tyrannical on account of the little advantages we think make us better than others; and on account of which we think that we deserve more than they do. Since human consciousness wishes to uphold its most cherished interests at all cost; and against all odds; especially against an outside it perceives as threatening and alien, it makes recourse to extreme measures to preserve its interests. Sensing itself as weak and incomplete, it makes recourse mostly to what I call the super maxim of the nearer the better and the safer. It does so mostly in view of forming a coalition of the weak or the strong, as the case may be, and in conjunction with those it identifies as sharing some bond of intimacy with it. Adhering strictly to the supermaxim, which is a hypothetical command, it elevates same to an absolute categorical command based on which human consciousness seeks dominance over those it identifies as threatening, weak or dispensable. We encounter experiences of this kind in almost all areas of our existential living, in small groups, in communities, in organisations, in international relations, in matters relating to distribution of scarce resources of the world, in exploitation and conservation of the eco system etc. Blindfolded by the little advantages bestowed by circumstances, stakeholders easily elevate such purely accidental qualities as our humanity, our achievement, our social status, our ethnic affiliation, the colour of the skin, religious affiliation, rank, gender etc., to absolute categories; and based on which they seek to dominate, exploit and subjugate those they perceive as alien and threatening to their interests. It is a fracture in human consciousness which knows no mediation and compels it always to seek its autonomy outside the foundation of its unity in being; and in ways that can be contrary to common sense. Restoring the human consciousness to an equilibrated state of mutual complementarity with all existent realities turns out to be one of the major challenges to which philosophy in the age of globalisation is exposed.

\section{The New Complementary Ontology of Ibuanyidanda and 21st Century Metaphysics}

Bearing in mind some of the difficulties associated with any ontology that can contribute in enhancing the fracture in human consciousness, a decisive question arises, namely: Is there a way to approach reality and uphold the notion of being such that our conception of reality can be harmonised beyond bifurcation and exclusivist tendencies? Again, how can substance and accidents be handled as mutually related categories beyond an understanding that handles them as bifurcated exclusivist categories? It is the question: How is a complementary integrated notion of being possible? Exploring a notion of being in this integrated complementary mode is bound to be one of the cardinal preoccupations of a 21st century metaphysics that takes differences arising from our heterogeneous multicultural nature of our world today seriously. In a globalised world where differences play a major role such a

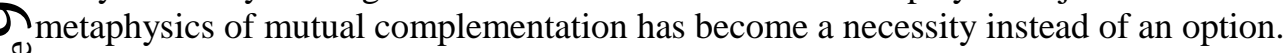
ळ్రTo attain this objective may entail a thorough review and reformulation of some basic presuppositions of metaphysics in view of aligning them to the demands of some of the major existential realities of our time; in ways that reconcile and 
harmonise; but not in ways that polarise and segregate. We are thinking here of issues relating to coexistence of peoples, to the totality of reality including the way we relate to the ecosystem.

Addressing issues of this kind entails reconceptualising metaphysics as the science of being qua being in its most abstract abstruse connotation and rendering it more concrete and more adaptable to existential issues. This task can hardly be accomplished where we assume that the notion of being qua being in its abstract abstruse connotation is indefinable in a certain way (STEENBERGHEN 1952, 2325). It is this near lack of interest to probe into the notion of being in the dynamism of its essentiality that has complicated matters for most forms of Western inspired types of metaphysics, and makes it difficult as a credible platform for building a healthy type of relationship between the subject and the totality of reality. Any metaphysics that should satisfy the demands of this new orientation must be grounded on integrated complementary foundation as to be able to overcome some of the most severe excesses of a metaphysics that bifurcates and absolutises. This alternate metaphysics is the new ontology of ibuanyidanda philosophy or complementary reflection as I conceive it. With this I pursue a new ontological horizon within which a complemented idea of beings can be made accessible beyond, for example, the substance - accident dichotomy that presents difficulties. Within the context of this new ontological horizon of ibuanyidanda to be is simply conceptualised as to be in mutual complementary relation (ka sọ mụ adina), whose negation is to be alone (ka sọ mụ di) and not nothingness. By implication, this means that that person is to be pitied who thinks that a subject can afford to live alone (ka so mụ di), outside of the legitimacy provided by mutual complementary relationship of all existent realities and call this existence. Such a new approach operates under the assumption that the notion of being is definable contrary to the claims of classical metaphysics. As a metaphysics of complementation, it is one that defines being as that on account of which anything that exists serves a missing link of reality (ihe di nwere isi na odu); and in tune with its claim as the science of missing links. Over and above all, should such a metaphysics be able to accomplish this enormous task, it must show its capacity to address credibly the issues arising from the inherent tension in human consciousness; something that is the real cause of most problems evident in any metaphysics that bifurcates and polarises.

In this way, I understand the new complementary ontology of ibuanyidanda philosophy as a transcendent complementary comprehensive existential analysis as to determine the reasons the ego always seeks its autonomy outside the foundation of its unity in being that is complementarily constituted. It is an inquiry into the reasons the broken unity in human consciousness persists despite the apparent goodwill that accompanies our actions. I seek thereby workable solutions how such challenges can be addressed and if possible eliminated. This task is for me nothing other than Darticulating an ontology in tune with my understanding of philosophy as a science of

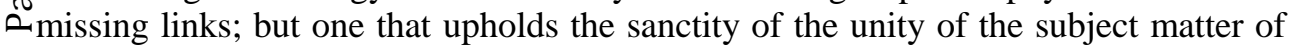
philosophy as a science that is ultimately constituted in a future referential absolute 
mode. It is thus an attempt at building a coherent system deriving from general ideas with an inherent logic of necessity based on which reality and human experience can be analysed and understood in an integrated mutually complementary mode. Within such a philosophical context, statements are applied with the evident insight that the notion of being derives its justification consistently from the dictates of the first principles as it affirms that anything that exists serves a missing link of reality. I seek to accomplish this task while relying on the principles, the method and allied tools of ibuanyidanda philosophy which are all geared towards expounding philosophy as the science of missing links of realty.

\section{Beyond A Reductionist Type of Hermeneutics and the Groundwork for the Dynamics of Self-discovery}

When we talk of authentic African existence, a certain question immediately comes to mind, i.e. are there experiences that can be universalised as to be termed authentically and uniquely African without exception? How we decide this question can have far reaching implications for the way we do philosophy and relate to things African generally. In answering this question, there are at least two types of reduction with which we have to contend: The first is anthropological and the second is diachronic. The first, the anthropological proceeds from the assumption of an abstract collective African ego from which all valid deductions can be made with regard to all statements and all persons of African descent. The second that is diachronic operates under the assumption that African past historical experiences, as these are deposited in traditional African life, are the most authentic African experiences ever; as such they offer the legitimatising foundation and point of reference for all subsequent experiences relating to Africa.

Assumptions enshrined in these types of reduction have hardly benefitted African philosophy where some of its practitioners think that African philosophy is a hermeneutics of culture of the type that dwells on interpretation of myths of yesteryears and not myths of today, magical attitudes of yesteryears and not magical attitudes of today; folklore of yesteryears and not those of today, traditional African thinkers of yesteryears and not those of today. If African philosophy must concentrate on analysing tales, myths and experiences of old, whose responsibilities are the contemporary experiences and future experiences? Here we easily forget that the myths and narratives of today are the very repository from which the hermeneutics of tomorrow derive. To restrict African experience to traditional African experience of a predetermined past, and to an overbearing abstract collective ego merely succeeds in undercutting the efficacy of hermeneutics as a science of interpretation and understanding of the totality of human experience. What these - approaches overlook is that even collective experiences are deeply rooted in - individual experiences and vice versa. When we approach reality with a bifurcated odype of mind-set, chances are that we handle the collective ego and the individual ego $\widetilde{D}$ as if they are contradictory categories. Hence, one of the greatest difficulties our historical process presents is how to uphold the legitimising role both of the 
individual and collective ego in a way that does not polarise and dichotomise them, but in a way that harmonises and complements them; in a way that does not diminish their importance, but in a way that enhances same. Our individual histories and the totality of human history are not exclusivist or contradictory to each other. On the contrary, they complement each other since our individual narratives, as interpreters, play very crucial role in determining the totality of the historical process. Remove the constitutive role of the individual and history loses its dynamism and validity.

The tendency to overlook the important place of our individual narratives has contributed greatly in retarding the pace of growth in African philosophy; and reducing it to an inquiry into the collective worldview of an abstract collective ego that determines and legislates over the consciousness of the totality of African experience of reality. This is why even till this day in African philosophy hermeneutics appears to be object oriented only, and not person oriented - a good cause for concern. This must not be the case since the experience of the individual has an undisputed emancipatory and legitimising role in the order of things. From individual experiences and insights derives the critique based on which we interpret and understand. In which case, the individual gives history its dynamism and puts it in check as it grows and expands. This is precisely why Ibuanyidanda, as a transcendent complementary existential inquiry, assigns enormous importance to understanding the structure and dynamics of human consciousness in the tensionladen condition of its existence. Where the individual experience vanishes in an all embracing and legitimising abstract collective ego, chances are that the individual ego can hardly attain the level of emancipation needed to interpret and understand more accurately. The insight deriving from adherence to the super-maxim of ibuanyidanda philosophy stands to testify in this regard. In our ability to relate credibly individual experiences to the experience of the collective, and in determining how they cohere in view of affirming all existential realities as missing links subsists the route to authentic experience. Here, we say that the collective and the individual are co-legitimising as they cohere to affirm insightfully that to be is to be in mutual complementary relationship. This insight is valid not only for issues dealing with Africa but for human experience of reality generally.

Hence, it is by remembering the position of the individual in the general scheme of things and in seeking ways to relate it to the collective in a mutually complementary mode that we can pursue hermeneutics as the art of interpretation and understanding geared towards the totality of our historical experiences. It is this type of orientation that is needed in upholding the authenticity of our individual existences within the demands of a collective. Granted our African culture forms the basis of our identity and experience, our being as Africans does not stop there. How we fit Ninto the general scheme of things is very crucial. Here, a mind-set deriving from a reductionist type of hermeneutics will hardly suffice. This is why it would hardly be ogto the interest of Africans to restrict the question of authentic African experience to that pristine experience deriving from our raw primary cognitive ambience only. Authentic Africa is not buried in the past neither is it enshrouded in an abstract 
collective ego. On the contrary, it is something that derives its dynamism from a world that keeps evolving in the complementarity of its interrelatedness. Here, Africans are integral parts of the totality of the invaluable resources needed for the evolution and transformation of the ideas determining human destiny. To isolate themselves from this dynamic process by holding romantically and fastidiously to some ideas, codes of conduct and values they consider uniquely theirs is tantamount to undermining their own interests in a world of mutual complementary experience. Bearing these points in mind, it will hardly suffice today when in our research procedure and in all other matters dealing with Africa we concentrate on seeking only African versions of everything; African science, African medicine, African time, African attitude etc. More often than not, and quite disquieting, some of the things that are seen as uniquely African leave much to be desired. In some contexts, some Africans are content with diminutive form of almost everything in the name of being unique and authentic. This is what I call "Africa the dwarf" mentality where the African is content with the diminutive African version of almost everything: A negative attitude to the world that derives from an internal expression of existential pessimism and scepticism concerning the capacity of the African to excel and transcend beyond the impositions of our raw primary cognitive ambience (ASOUZU 2004, 254-265; 2007a, 111-119).)

This is why even, if we do science, we do so as individual Africans. We do so as again Africans, who are an integral part of the totality of human experience seeking viable solutions to the problems of the world. Such has always determined the way scientific researches are conducted as teamwork of experts drawn from heterogeneous backgrounds, where each represents his creativity and the creativity of the team. Those who think that only the past and the collective historical ego is what matters most, are they saying that the efforts of contemporary African researchers who write papers, teach, do research and participate at international events and conferences are not part of the solution of world problems? Are they saying that achievements of Africans in their diverse fields of specialisation have to be ascribed to the others, just because they happen to be Africans? It is this capacity to embrace reality in a complementary, whole, future related mode that gives science its justification as human experience. Hence, hermeneutical dexterity subsists in pursuing it in the type of fusion of horizon bestowed by what I call the experience of transcendent complementary unity of consciousness (ASOUZU 2007, 323-327). This is that transcendent experience through which stakeholders acquire the clear and indubitable insight into the fact that being in its ultimate mode of manifestation evinces itself as missing links of reality. Any hermeneutics that is reductionist misses this point and delimits our capacity to penetrate reality in this transcendent Mcomplementary mode. It is such reductionist hermeneutics that operates from the assumption, for example, that African medicine is reducible only to remnants of oxtraditional African healing methods and has nothing to do with the successes African $\widetilde{\Omega}_{\text {scientists }}$ record daily in their clinics, in their research laboratories, in the classrooms, in embracing insights deriving from more refined quantitative methods 
of analysis. Since all forms of reductionism are unduly dogmatic, conservative and backward-looking, they deny even the most honest and hardworking African scientists their contributions in the growth of knowledge that is complementary in constitution. This is valid in all branches of endeavour because our ideas in their genesis, excogitation and further development are complementary beyond ethnic and geographical confines.

What this implies is that that all matters dealing with, self-affirmation, selfreliance and personal autonomy have to be handled within a complementary framework. If we handle and isolate Africa from a world of heterogeneous composition because of what we identify as its unique and authentic characteristics, we risk denying it its valuable affinity with a world whose legacies owe its richness to mutual complementarity. If we handle Africa differently, she is not entitled to the claims and benefits accruing from the mutual complementary genesis of ideas and other human values. Attempts at seeking only those things that are uniquely African or unique to any peoples of the world for that matter is bound to boomerang since all human achievements and failures can be thought of only within the context of mutual complementarity. Here, human heritage upholds its worth when all complement their efforts in full consciousness of their mutual dependence as beings that are finite and in need of completion. A bifurcated and exclusivist attitude to the world will hardly satisfy the demands of a philosophy that sees all things as missing links of reality. Hence when we talk of authentic African experience such is possible only within a context of mutual complementary relationship of all missing links of reality.

\section{Relevant Literature}

1. ARISTOTLE. [Metaphysica, W. D. Ross Ed.], 1926. Vol. VIII, Second Edition. Clarendon Press: Oxford. Web.

2. ASANTE, Molefi Kete. [The Afrocentric Idea], 1987. Philadelphia: Temple University Press. Paperback.

3. ASOUZU, I. Innocent. [Kritische Betrachtung der konstruktiven Wissenschaftstheorie. Erwägungen zu praktisch-philosophischen Konfliktregelungsstrategien], 1984. Hildesheim, Zurich, New York: Georg Olms Publishers. Paperback.

4. ___. "Eine Analyse und kritishe Bewertung der Methode und des Prinzips der praktischen Argumentation Oswald Schwemmers.” [Conceptus, Journal of Philosophy], Vol 18. No 4. Pp 85-103, 1984. Paperback. 
$5 . \quad$ __ [ [Gedanken über die religiöse Problematik der Gegenwart im Licht der Theologie derReligionen], 1986. Frankfurt, Bern, New York: Peter Lang Publishers. Paperback.

6. __ [The Method and Principles of Complementary], 2004. Calabar University Press: Calabar. Paperback.

7. ___ "Redefining Ethnicity within 'The Complementary System of Thought' in African Philosophy." [Re-ethnicizing the Minds? Cultural Revival in Contemporary Thought, Thorsten Botz-Bornstein and Jürgen Hengelbrock Eds.], 2006. Amsterdam/New York. Paperback.

8. ___ [Ibuarụ: The Heavy Burden of Philosophy beyond African Philosophy], 2007a. Münster, Zürich, New Brunswick, London: Litverlag. Paperback.

9. _ _ [Ibuanyidanda. New Complementary Ontology. Beyond WorldImmanentism, Ethnocentric Reduction and Impositions], 2007b. Münster, Zurich, New Brunswick, London: Litverlag. Paperback.

10. - [Ibuanyidanda (Complementary Reflection) and Some Basic Philosophical Problems in Africa Today. Sense Experience, "ihe mkpuchi anya" and the Super-maxim], 2013. Münster, Zurich, Vienna: Litverlag. Paperback.

11. AYER, A. Jules. "The Impossibility of Metaphysics." [Science, Faith, and Man. European Thought since 1924, W. Warren], 1968. London: Wagar. Paperback.

12. . "Demonstration of the Impossibility of Metaphysics." [Mind] Vol. XLIII, 334-345, (July) 1934. Paperback.

13. BECK, Heinrich. "Europe-Africa-Asia: The Creative Proportion between the World Cultures." [Thought and Practice in African Philosophy, Gail M. Presbey et al. Eds.], 2002. Konrad Adenauer Foundation: Nairobi. Paperback.

14. CHIMAKONAM, O. Jonathan. "History of African Philosophy." [Internet Encyclopaedia of Philosophy]. Available at: http://www.iep.utm.edu/africhi/ Web. 
15. COPLESTON, Frederick. [A History of Philosophy: Volume 1, Greece and Rome, Part II], 1960. Image Books: New York. Paperback.

16. CORETH, Emerich. [Metaphysik. Eine methodish-Systematische Grundlegung], 1963. Tyrolia: Innsbruck. Paperback.

17. DALLMAYR, Fred. "Empire or Cosmopolis. Civilization at the crossroads." [Denktraditionen im Dialog: Studien zur Befreiung und Interkulturalität, hrsg. Von Raúl Fornet, Betancourt], Band 22, Frankfurt 2005. Paperback.

18. DOUGHERTY, Kenneth. [Metaphysics. An Introduction to the Philosophy of Being], 1965. Graymoor Press: New York. Paper.

19. GRANESS, Anke. Einleitung zu Kimmerle „Die schwere Last der Komplementarität. Antwort auf Innocent I. Asouzus Kritik an der interkulturellen Philosophie.“ [Polylog. Zeitschrift für Interkulturelles Philosophieren]. 19, 2008. Web

20. HIRSCHBERGER, Johannes. [Geschichte der Philosophie I, Freiburg], 1976. Wien: Basel. Paperback.

21. KIMMERLE, Heinz. „Die schwere Last der Komplementarität. Antwort auf Innocent I. Asouzus Kritik an der interkulturellen Philosophie.“ [Polylog. Zeitschrift für Interkulturelles Philosophieren]. 19, 2008. Web.

22. __ [Philosophie in Afrika - afrikanische Philosophie Annäherungen an einen interkulturellen Philosophiebegriff]. http://www.galerieinter.de/kimmerle/philafr.htm Web.

23. SAHAKIAN, William. [Outline-History of Philosophy. From the Earliest Times to the Present], 1969. Barnes and Noble: New York.

24. POPPER, Karl R. "Wie ich die Philosophie sehe" [Conceptus. Österreichische Philosophen und ihrer Einfluss auf die Analytische Philosophie der Gegenwart], Band I, 1977. Paperback.

25. TEMPELS, Placide. [Bantu Philosophy], 1959. Presence Africaine: Paris.

26. VAN STEENBERGHEN, Ferdinand. [Ontology, Martin J. Flynn Trans.], 1952. Joseph F. Wagner: London. 